\title{
Reports from the Local Societies
}

There is one society from which there is no report for 1959-the Saltcoats Conservation Club was disbanded about a year ago because no one would accept the office of president when Frank Baines retired at 82 years of age. We are sorry to lose this contact witl: Saltcoats naturalists and our good friend Frank Baines, president of the club for many years, but we hope that a club can be formed there again. Our new president, Dr. Bob Nero, hopes that we shall have a number of new clubs this year.

Garden River-The main project of the Garden River Natural History Society this past year has been concerned with the young people of the community, now organized as a junior naturalists' group calling themselves the "Sea Gulls." These junior naturalists have been partipating in bird counts and recording their observations. The club as a whole had a number of expeditions this spring attempting to locate Goshawks' nests, following the visit to the club by Richard Fyfe and ris falconry group.

Moose Jaw-During the past year the Moose Jaw club has doubled its membership from 35 to 70 . Meetings are now held at the Public Library the second Friday of each month. The club had a successful Christmas count, and a series of nine spring field trips, plus two joint outings with the Regina Natural History Society's bird group (one in the spring and one in the fall). The A.O.U. meetings in Regina were attended by 21 members. Their present project is a winter bird feeding programme, encouraging members and others to put up feeding trays, and distributing mimeographed material to the schools. The Moose Jaw club played host to the annual meeting of the S.N.H.S on October 16-17.

Prince Albert-Among the meetings and field trips arranged by the P.A. club was a popular visit from Richard Fyfe and his falcons. Main project for the year ras been the setting up of a standard sample plot in the mixed wood forest north of Christopher Lake. It is proposed to make as complete as possible a biological inventory of this area, and each member of the executive is responsible for organizing the investigation of a particular subject.

Regina-In addition to regular monthly meetings, the Regina society has sponsored in the past year the Audubon Screen Tours and the Sunday "World Wandering" Shows in the Museum. It presented an aquarium to the Museum, and had martin houses made for location in Wascana Park nearby. As one of the official sponsors of the A.O.U. meeting in Regina, the club assisted with the reception in the Art Gailery following the Bird Art Show, and provided a picnic supper on the Museum lawn. Earlier in the year a reception was arranged in connection with the Bird Photography display in the MacKenzie Art Gallery.

Saskatoon - The society holds monthly meetings from September to May with popular programmes of films, speakers, etc. This spring a series of field trips was sponsored under the leadership of Bob Folker, featuring birds, plant identification and ecology, aquatic plants and invertebrates, and geology.

Yorkton-The club reports little activity this year, but one of its members, Dr. Stuart Houston, has published an important book on the birds of central Saskatchewan.

\section{REGISTRATION}

Registered at the annual meeting of the Saskatchewan Natural History Society, October 16 and 17, were 102 persons from 13 different Saskatchewan points, with one visitor from Vancouver.

Fort San: Mr. and Mrs. E. M. Callin.

Indian Head: Rose McLaughlin.
Kindersley: Glen Fox.

Lloydminster: H. C. Weaver.

Maple Creek: Mr. and Mrs."G. MacMillan.

Melville: Gary Anweiler.

Moose Jaw: Mrs. F. B. Taylor, Dr. and Mrs. D. Ewart, Patricia Douglas, Judy and Becky Ewart, Mrs. Dorothy Rhodes, Michael Rhodes, Mrs. Mary 